\title{
Analysis Of Village Building Index In Village Development In Kuala Sub-District
}

\author{
Ar Royyan Ramly ${ }^{1}$, Wahyuddin ${ }^{2}$, Julli Mursyida ${ }^{3}$, Mawardati ${ }^{4}$ \\ 1.2 Department of Islamic Studies, Universitas Serambi Mekkah, Aceh. \\ ${ }^{3.4}$ Department of Economic and Bussines, Department Agriculture Malikussaleh \\ University, Aceh. \\ arroyyanramly@serambimekkah.ac.id
}

\begin{tabular}{|c|c|}
\hline Article Info & Abstract \\
\hline $\begin{array}{l}\text { Clause history: } \\
\text { Received April 10,2019 } \\
\text { Revised July 15,2019 } \\
\text { Accepted July 27,2019 } \\
\text { Available online August } \\
28,2019\end{array}$ & $\begin{array}{l}\text { This study aims to analyze the village building index } \\
\text { in the development of village in Kuala sub-district of } \\
\text { Nagan Raya regency. This research is descriptive } \\
\text { qualitative and quantitative. The object of this study is } \\
17 \text { villages in the region of Kuala sub-district, while the } \\
\text { data used in this study is sourced from primary and } \\
\text { secondary data derived from document review, }\end{array}$ \\
\hline $\begin{array}{l}\text { Keywords: Environmental } \\
\text { Sensitivity Index, } \\
\text { Economic Conditions } \\
\text { Index, Healthy Family } \\
\text { Index and Village Building } \\
\text { Index } \\
\text { JEL Classification : D6, } \\
\text { A1, B55, O1 }\end{array}$ & $\begin{array}{l}\text { observation, FGD, and interviews from } 2015 \text { to } 2017 \text {. } \\
\text { Data analysis technique using descriptive analysis in } \\
\text { the form of tables and diagrams, while the quantitative } \\
\text { analysis using multiple regression test with the } \\
\text { dependent variable percentage of village fund } \\
\text { accumulation 2015-2017, independent variables are } \\
\text { Environmental Sensitivity Index, Economic } \\
\text { Conditions Index, Healthy Family Index and Village } \\
\text { Building Index. The results showed that the analysis of } \\
\text { the use of village funds for development in Kuala sub- } \\
\text { district positively influence. Then with the } \\
\text { development of village infrastructure and } \\
\text { empowerment, the status of villages in the region of } \\
\text { Kuala sub-district increased with an average } \\
\text { developing status of } 71 \text { percent and advanced village } \\
\text { status of } 23 \text { percent. }\end{array}$ \\
\hline
\end{tabular}

\section{INTRODUCUTION}

The village is a legal community unity that has the boundaries of the territory authorized to regulate and administer government affairs, the interests of local communities based on community initiatives. The term village is often synonymous with poor, traditional, and conservative society (Misbahul and Jatmiko, 2012). Although the construction of the village has been a while but there are still problems faced by villages and requires completion soon until now, such as issue of the low as the ability of human resources, administration that is not inline (Ramly and Mursyida, 2017), including the issue of poverty that has always been a major issue of village development (Ramly \& Mursyida, 2018).

The government has paid special attention to village development and empowerment. One of it with the enactment of law No. 6 of 2014 on the village. This law is very helpful to the government of the village in the management and considered more facilitate in the implementation of village governance due to more detailed rules. Rahmawati explained in his research that the village is 
ready in implementation of the implementation of Law No. 6 of 2014 on the previous village, the management of village finances based on Law no. 32 of 2004 on Regional Government and it is part of regional finance (Rahmawati, 2015).

The implementation of the constitution is expected that village governments can manage village potential independently based on the resources that they have, including village financial and wealth management. Therefore, village governments should be able to apply the principles of transparency and accountability (Azwardi and Sukanto, 2014). In its governance, where all the end of village governance activities should be able to realize the village development, both in improving the welfare of life, the development of village facilities and infrastructure, the development of local economic potential, the utilization of natural resources and sustainable development of the environment.

The allocation of village funds is an elaboration of the sustainable development of village programs ( Sustainable Development Goals/ SDGs) In this regard, the main objectives of the Village Fund are: a. Improving the implementation of village governance in implementing governmental, development and community services in accordance with the authority, $b$. Improving the capacity of Community Institutions in the village in the implementation planning and development control in a participatory manner in accordance with the village potential, c. Increasing equitable income of employment opportunities and business opportunities for rural communities, d. Encouraging the improvement of community mutual assistance (KOMPAK, 2017).

Government efforts to develop the village through the allocation of the village funds, requires scientific evaluation to measure and compare the results of which have been implemented with the condition of the village before the presence of allocation of village funds, such as the sample on this study, that is Kuala sub-district of Nagan Raya regency, there are people which is below the poverty line that does not have access to the utilization of village development. This condition is very inversely proportional to the potential possessed by Kuala sub-district, such as areas 3,544.90 hectares with potential for forests, seas, estates and mines with economic growth of 3.89 percent in 2015. However, the percentage of poor population in Nagan Raya is still high around 20.13 percent in 2015 , this percentage is better than the previous year with a percentage of 24 to 33 percent the number of poor and 19:25 percent in 2017, Kuala sub-district also has 17 villages in the strategic area and economic boost of the people, the central access for the community with the line of territory connecting between regencies in Aceh Province, in addition, the position of the Kuala has access to the central market and public service centers such as offices, and local hospitals. While, the status of the villages in this region is generally classified into the underdeveloped village based on the building village index in 2015 (Ministry of Village, Development of backward area and Transmigration, 2015). 
Therefore, the purpose of this study is to analyze the use of village funds on the development of village status in Kuala sub-district for the last 3 years. Village status can be measured through the village building index with the goal of seeing sustainable impacts for village progress and welfare. The Building Village Index gives the status of villages classified into independent villages, advanced, developed, left behind, and very left behind.

So Based on the description above then the formulation of the problem in this paper is how the development of village status Kuala sub district measured through village building index? Is there a significant effect on development in Kuala sub-district after the allocation of village funds is implemented? The conclusion of this paper is expected to be an input to the stakeholders in evaluating the implementation of the funding of the village especially in Kuala sub-district of Nagan Raya regency.

\section{METHOD}

This research is qualitative descriptive (Sugiyono, 2006), based on village building index data of each village in Kuala sub-district of Nagan Raya District. For the purposes of policy formulation and direction of future village developments, a literature study related to the village development program or empirical experience was undertaken. The object of research is Kuala subdistrict that there are 17 villages. This study uses primary data sources obtained directly from villages, sub-district offices, village counselors and the community.

While Secondary data is obtained from regulatory documents, planning and reporting. The informants in this study consisted of directly or indirectly related parties, i.e. local government officials, village government officials, such as village heads, village secretaries, heads of affairs, Chairmen/Members of Village Consultative Bodies, community elements from community groups, community in the village, are obtained by purposive sampling where the researcher determines the sample based on certain decision and consideration. Data collection techniques in this study consisted of interviews, questionnaires, FGD, and document observation. The analysis technique used is descriptive and quantitative analysis. Descriptive analysis used to describe the characteristics of variables studied include the analysis of the average, the highest value, the lowest, and the cross table. In addition, an analysis is used to describe the amount and percentage or proportion information. The analysis results are presented in the form of tables or graphs (Miles and Huberman, 1992). While the quantitative analysis uses multiple regression of Environmental Sensitivity Index, Economic Conditions Index, and Healthy Family Index

\section{Variable Operational}

The Village Fund is a fund sourced from State budget which is reserved for the transferred Village through the Revenue and Expenditure Budget District /Town Region and used for finance the administration, implementation of development, coaching community, and empowerment community. To Analyze the Use of Village Funds can be seen in the

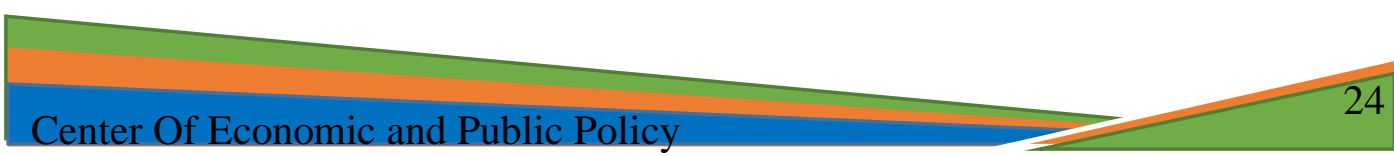


Expenditure Budget District /Town Region and the realization reports of each phase of village funds disbursed (Rianto and Junaedi, 2017). Village funding variables derived from the accumulation of realization of village development during the 2015-2017 periods from the allocation of village funds. Village building index is a composite index generated from the average Environmental Sensitivity Index, economic endurance index and social endurance index of each village.

\section{Research Model}

Approach in this research, is approach of qualitative method, to get expected result of research, hence framework of research model developed as follow:

Figure 1 Research Model

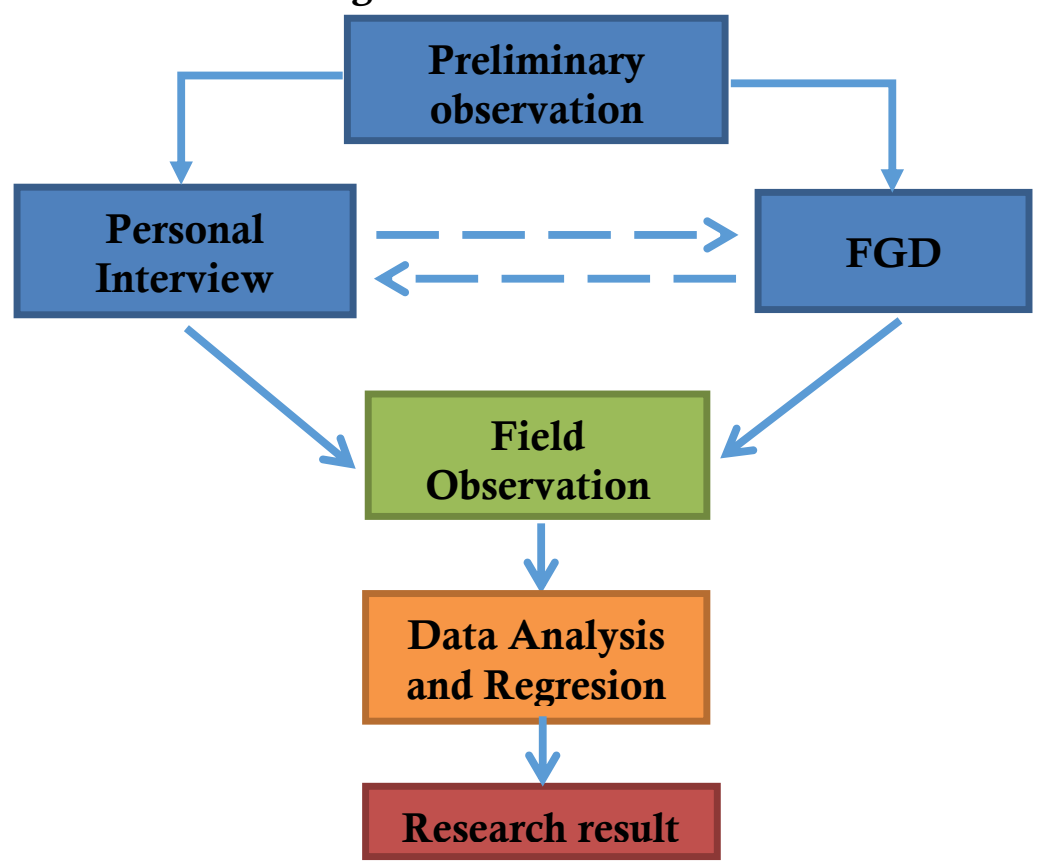

Source: Setyobakti 2017

\section{RESULT AND DISCUSSION}

Kuala sub-district is one of the districts in Nagan Raya regency which has an area of $120,89 \mathrm{~km} 2$. Its Location of territory is to the north abuts with Suka Makmue Sub-district, to the South is bordered by Kuala Sub-district Coastal. To the east is bordered by Tadu Raya sub-district. While to the West is bordered by West Aceh Regency. Topographically of the region, all villages in this subdistrict are located in the land area. Its territory is not bounded by sea. There are two villages located on the edge / surrounding forest area. While the rest (15 villages) is outside the forest area (BPS, 2016).

Kuala sub-district is a densely populated area and located in the lowlands. Most of the population lives on plantations, agriculture, the service sector, trade, carpentry and other information sectors. Kajen Sub-district is directed to infrastructure that aims to facilitate the flow of transportation. 
Table 1. Villages Within The Region Kuala Sub-Dist.

\begin{tabular}{cll}
\hline NO & \multicolumn{1}{c}{ VILLAGES } & \multicolumn{1}{c}{ VILLAGE HEAD } \\
\hline 1 & Lawa Batu & M. Arsyad, S.Sos \\
2 & Jogja & Ali Riadi \\
3 & Ujong padang & Miswanto \\
4 & Ujong patihah & Nazar Mawi \\
5 & Ujong Pasie & M. Yasin \\
6 & Simpang Peut & Sahabuddin \\
7 & Blang Teungoh & Yahya Ubit \\
8 & Blang Bintang & Erwan Syawarni \\
9 & Alue Ie Mameh & Abdullah Basyah \\
10 & Kuta Makmue & Djailani N \\
11 & Gunong Reubo & Djamrozi Ahmad \\
12 & Cot Kumbang & T. Ibrahim \\
13 & Puloe Ie & R. Meidi TS \\
14 & Ujong Sikuneng & Bustanul Arifin \\
15 & Blang Muko & Jauhari \\
16 & Blang Baroe & Nyak Hasan \\
17 & Purworejo & Ishak \\
\hline
\end{tabular}

Source: Secretariat of Kuala Sub-dist.

Then the above villages will be measured through the Building village index by looking at the indicators that have been prepared, such as the index of ecological endurance, economic endurance index and social endurance index. From the comparison of this index it will be seen the status of the village in the district of Kuala sub-district of Nagan raya regency. Based on existing data, the percentage of villages with underdeveloped and highly underdeveloped category in the province of Aceh shows the highest value compared to other provinces.

Based on data, it is seen that the percentage of villages with backward status in the province of Aceh reaches $64.7 \%$, and the percentage of villages with category of very disadvantage to reach $14.8 \%$ of the total number of villages in Aceh province by 2015. Table 1 also shows the value of village building index in the province of Aceh only reaches 0.552 . This condition shows that in general the progress and independence of villages in the province of Aceh are still lagging behind from other villages in Indonesia. While for village building index per/regency average occupy the status of lagging/backward. Nagan Raya Regency with village building index value of 0.53 while the composite index of Environmental Sensitivity Index is 0.63 , Healthy Family Index is 0.40 , and Village Building Index is 0.56 . This is an average index among a number of districts / cities in the province of Aceh. The building village index in the province of Aceh is 65 percent behind the village and only 19 percent of the villages are developing, while the very remote village has a 15 percent percentage. A very remote village in the Aceh has a wide distributions, the average of very remote villages is located in the highlands and islands. The following village building index data Kuala Sub-Dist. 
Table 3. Village Building Index Kuala Sub-dist 2017

\begin{tabular}{|l|c|c|c|c|c|}
\hline \multirow{2}{*}{ Villages } & \multicolumn{4}{|c|}{ Composite Index } & \\
\cline { 2 - 5 } & $\begin{array}{c}\text { Environmental } \\
\text { Sensitivity } \\
\text { Index }\end{array}$ & $\begin{array}{c}\text { Economic } \\
\text { Conditions } \\
\text { Index }\end{array}$ & $\begin{array}{c}\text { Healthy } \\
\text { Family } \\
\text { Index }\end{array}$ & $\begin{array}{c}\text { Village } \\
\text { Building } \\
\text { Index }\end{array}$ & Category \\
\hline Ujong Patihah & 0.81 & 0.63 & 0.87 & 0.77 & Advanced \\
\hline Blang Teungoh & 0.72 & 0.66 & 0.87 & 0.75 & Advanced \\
\hline Cot Kumbang & 0.71 & 0.58 & 0.86 & 0.72 & Advanced \\
\hline Simpang Peut & 0.80 & 0.85 & 0.73 & 0.79 & Advanced \\
\hline Blang Bintang & 0.67 & 0.42 & 0.60 & 0.56 & Backward \\
\hline Ujong Padang & 0.75 & 0.53 & 0.80 & 0.69 & Growing \\
\hline Jogja & 0.72 & 0.51 & 0.66 & 0.63 & Growing \\
\hline Lawa Batu & 0.73 & 0.43 & 0.80 & 0.65 & Growing \\
\hline Blang Muko & 0.68 & 0.48 & 0.73 & 0.63 & Growing \\
\hline Blang Baroe & 0.68 & 0.63 & 0.80 & 0.70 & Growing \\
\hline Purworejo & 0.73 & 0.48 & 0.80 & 0.67 & Growing \\
\hline Ujong Sikuneng & 0.70 & 0.41 & 0.80 & 0.64 & Growing \\
\hline Puloe Ie & 0.69 & 0.48 & 0.80 & 0.67 & Growing \\
\hline Kuta Makmue & 0.69 & 0.30 & 0.80 & 0.599 & Growing \\
\hline Gunong Reubo & 0.69 & 0.30 & 0.80 & 0.597 & Growing \\
\hline Ujong Pasi & 0.65 & 0.37 & 0.80 & 0.60 & Growing \\
\hline Alue Ie Mameh & 0.74 & 0.38 & 0.80 & 0.64 & Growing \\
\hline
\end{tabular}

Graph of channeling of village funds in 2015 to 2017 is increasing. In 2015 the total village funds disbursed in the sub-district reached $\mathrm{Rp} 5,436,347,000$ from regional general cash account, and total village funds in 2016 amounting to Rp. 14,374,730,490 are distributed, while in the year 2017 funds channeled to Kuala sub district of Rp. 18,020,030,052.

Building village index in 2017 in Kuala sub-district increased from 2016, average village in Kuala sub-district occupy lagging level compared to developing village. However, in 2017 it is seen that some villages in the previous level have grown to increase, such as Simpang Peut village, Ujong Patihah, Teungoh Blang, and Cot Kumbang. Geographically, the locations of these villages are located in the administrative center of Kuala Sub-district and very close to public facilities and infrastructure, such as school houses, offices, hospitals, shops, hotels and banking, in indicators of social, economic and environmental resilience indexes with close access distances. In addition, the facilities and infrastructure owned by the village are also sufficient as villages with village- owned enterprise (Bumdes) that can increase village income.

Meanwhile, there are 12 villages in Kuala sub-district such as Ujong Padang village, Jogja, Lawa Batu, Blang Muko, Blang Baroe, Purworejo, Ujong Sikuneng, Puloe Ie, Makmue Kuta, Gunong Re Ubo, Ujong Pasi, and Alue Ie Mameh compared in the previous year, the level of the lagging village also increased to the status of the developing village, the position of the developing village was located not far from the sub-district office center and 
close to public facilities such as school houses, hospitals, shops, etc. Besides, the supporting facilities and infrastructure in the village are also qualified after the utilization of the village fund allocation for the last three years, so that the village can plan the development and empowerment in the village based on the right of origin and authority of the village government. Ironically, however, the poverty and unemployment rates in the village are still high from year to year, while the decent living numbers in the village are getting smaller with the development of infrastructure in the villages.

The percentage of existing village status in the District of Kuala subdistrict of Nagan Raya Regency, which sourced from the building village index in 2017. The percentage shows only lagging that is as much as 1 village, 71 percent with developing village status as many as 12 villages, and 23 percent with advanced village status as many as 4 villages in sub-district of Kuala. This percentage has shown that the building village index in the average of Kuala sub-district in average increased the level of 71 percent of developing villages and 23 percent of the advanced villages out of a total of 17 villages in the subdistrict of Kuala. The researcher's assumption of increasing this index which is measured from Village Building Index also cannot be separated from the utilization of village fund which has been distributed by central and regional government which sourced from state/ regional budget. However, to see the significance of the effect of the use of village funds on rural development will be through a statistical approach. Where the village index construct which has three indicators of Environmental Sensitivity Index, Economic Conditions Index and Healthy Family Index will be measured influence significance with village funds used, this is in accordance with research of Riyanto and Junaedi (2017).

\section{Hypothesis Testing}

The results of this research hypothesis regarding the utilization of village funds on village development using Village Building Index indicators can be seen in the table below:

Table 4. Multiple Regression Results

\begin{tabular}{ccccc}
\hline Variables & Beta & $\mathbf{t}$ & Sig & Conclusion \\
\hline IKL & 4.504 & 4761 & 0.001 & $\mathrm{H}_{1}$ Accepted \\
\hline IKE & 5.824 & 4.290 & 0.002 & $\mathrm{H}_{2}$ Accepted \\
\hline IKS & 1.139 & 3.606 & 0.005 & $\mathrm{H}_{3}$ Accepted \\
\hline IDM & -8.393 & -8.393 & 0.001 & Significant
\end{tabular}

Source: data processed

From the table above the assumption of statistical test on environmental sensitivity index has positive effect with $p$-value equal to 0.001 less than assumption $\alpha=0.05$, economic endurance index also have positive effect with $p$-value equal to 0.002 less than assumption $\alpha=0.05$, and social endurance index have positive effect with $p$-value equal to 0.005 less than assumption $\alpha=$ 0.05 . While village building index has a p-value of 0.001 less than the

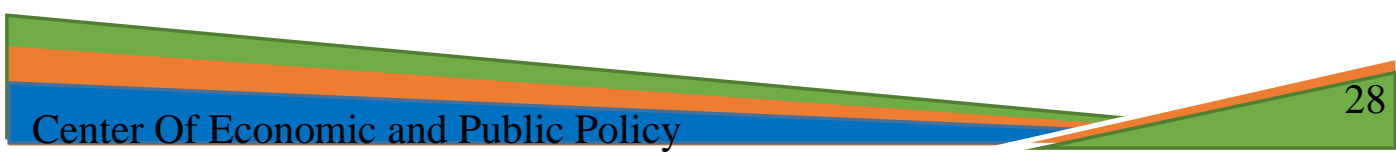


assumption $\alpha=0.05$. Building Index village of Kuala sub-district of Nagan Raya regency has a positive influence on the use of village funds in the development of villages in Kuals sub-district. This means that the distribution of village funds used for village development has an impact on rural development.

\section{CONCLUSION}

From the above discussion we can draw the conclusion that the analysis of building village index village building index by using indicators of Environmental Sensitivity Index, Economic Conditions Index and Healthy Family Index, in 2017 in the villages of Kuala sub-district has increased the status of village level. The average village is categorized as qualified with a developing status of 71 percent out of a total of 12 villages, while with advanced status of 23 percent of the total 4 villages, and only 6 percent with the status of backward village with only 1 village. Then from the results of statistical tests showed the results that the use of village funds in Kuala sub-district have positive effect on improving the status of village in the analysis of the building village index. The test result showed that the indicators of Environmental Sensitivity Index have positive effect and the Economic Conditions Index has positive effect, also the Healthy Family Index indicator has the positive effect.

\section{REFERENCE}

Abidin, M.Z (2015). Tinjauan Atas Pelaksanaan Keuangan Desa Dalam Mendukung Kebijakan Dana Desa (Study Of Implementation Of Village Finance To Support Fund Village Policy). Jurnal Ekonomi \& Kebijakan Publik, Vol. 6 No. 1.

Adisasmita, R. (2006). Membangun Desa Partisipatif. Yogyakarta: Graha Ilmu.

Azwardi \& Sukanto, (2014). Effectiveness of Village Fund Allocation (ADD) and Poverty in South Sumatera Province, Journal of Economic \& Development 12(1), 29-41.

BPS. Statistik Daerah Kecamatan Kuala 2016. BPS Nagan Raya.

Daldjoeni dan Suyitno.(2004). Perdesaan, Lingkungan Dan Pembangunan. Bandung: PT Alumni.

Halim, A. (2004). Bunga Rampai Manajemen Keuangan Daerah. Edisi Revisi. Yogyakarta: UPP AMP YKPN.

Kementerian Desa, Pembangunan Daerah Tertinggal Dan Transmigrasi. (2015) Indek Desa Membangun 2015.

Miles, M.B. \& Huberman, A.M. (1992). Analisis Data Kualitatif. Jakarta: UI Press.

Miles, M.B., Huberman, A.M. (1994), Qualitative Data Analysis. 2nded. Thousand Oaks, CA: Sage Publications. 
Misbahul, A.dan Jatmiko, B. (2012). Kontribusi Dan Peran Pengelolaan Keuangan Desa Untuk Mewujudkan Anggaran Pendapatan Dan Belanja Desa Yang Transparansi Dan Akuntabel (Survey Pada Perangkat Desa Di Kecamatan Ngaglik, Sleman, Yogyakarta). Jurnal Universitas Muhammadiyah Yogyakarta.

Permen Dalam Negeri Nomor 51/2007.

Purwaningsih, E. (2008). Partisipasi Masyarakat Dalam Pembangunan Desa. Jurnal Jantra, 3(6), 443452.

Rahmawati, H.I. (2015). Analisis Kesiapan Desa Dalam Implementasi Penerapan UU Nomor 6 Tahun 2014 Tentang Desa (Studi Pada Delapan Desa Di Kabupaten Sleman). The 2nd University Research Coloquium 2015 ISSN 2407-9189.

Ramly, A. dan Wahyuddin, (2017). Implementasi Kebijakan Dana Desa Dalam Pengelolaan Dan Peningkatan Potensi Desa (Studi Kasus Kec Kuala Kabupaten Nagan Raya), Seminar Nasional II USM 2017 Eksplorasi Kekayaan Maritim Aceh di Era Globalisasi dalam Mewujudkan Indonesia sebagai Poros Maritim Dunia Vol. 1, 379-392.

Ramly, A. dan Wahyuddin, (2018). The Model and Strategy Improved of Empowering Economic Community Based on Village Fund Allocation: Empirical Study in Kuala Sub district, Nagan Raya District), Advanced Science Letters Vol. 24, 362-364.

Riyanto dan Junaedi (2017). Implikasi Penggunaan Dana Desa Terhadap Ketahanan Sosial, Ekonomi, dan Ekologi Desa Tertinggal di Kabupaten Karanganyar. Jurnal Sainstech Politeknik Indonusa Surakarta ISSN : 23555009 Volume 4 Nomor 2 Desember 2017.

Setyobakti, H. M. (2017). Identifikasi masalah dan Potensi Desa Berbasis Indek Desa Membangun di Desa Gondowangi Kecamatan Wagir Kabupaten Malang. Jurnal Penelitian Ilmu Ekonomi WIGA, 7, 1-14.

Sofianto, A. (2017). Kontribusi Dana Desa terhadap Pembangunan dan Pemberdayaan Masyarakat di Kebumen dan Pekalongan. Matra Pembaruan Daerah (Bappeda) Provinsi Jawa Tengah. Jl. Pemuda No, 1(1), 23-32.

Sugiyono. (2006). Metode Penelitian Kuantitatif, Kualitatif dan R\&D (Qualitative and Quantitative Research Methods). Bandung: Alfabeta.

Team KOMPAK (2017). Policy Analysis Village Fund and Poverty Allevation. Jakarta: Australian-Indonesian Government Patnership. Page (1-8).

UU No 6 Tahun 2014 tentang Desa (2014). Republik Indonesia.

Permendes No 2 Tahun 2016 Tentang Indeks Desa Membangun.

Oktaviana, O. dan Bachruddin, D.T, (2017), The Efforts to Improve Developing Village Index in Banten Province Region Through Policy 
\begin{tabular}{r|l} 
Analysis Of Village Building Index In Village Development In Kuala Sub- & $\begin{array}{l}\text { Ramly } \\
\text { Wahyuddin } \\
\text { District }\end{array}$ \\
Mursyida \\
Mawardati
\end{tabular}

Intervention of Provincial Government, Conference: Seminar Nasional Laboratorium Administrasi Publik 2017 "Pengembangan Kawasan Berbasis Pembangunan Berkelanjutan". 